\title{
ПРАВООХОРОННА ДІЯЛЬНІСТЬ
}

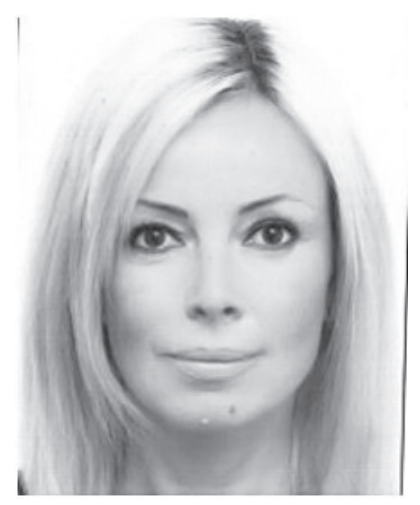

УДК 347.963 (477)

\author{
Ірина Русанова, \\ кандицат юридичних наук, Аоцент, \\ доцент кафредри судоустрою \\ та прокурорської Аіяльності \\ Національного юридичного університету \\ імені Ярослава Мудрого
}

ORCID: 0000-0001-5718-4320

https://doi.org/10.32782/2306-9082/2020-39-20

\section{Суб'єкти розв'язання питання щодо дисциплінарної відповідальності прокурорів}

Сучасний етап реформування прокуратури в України характеризується великою кількістю трансформаційних змін, зокрема пов'язаних зі зміною відповідних механізмів у кадрових питаннях. Однією з важливих кадрових процедур є дисциплінарна відповідальність прокурорів, адже ії особливий порядок поруч із порядком призначення на посаду, звільнення прокурорів із посади визначається в п. 1 ч. 1 ст. 16 Закону України «Про прокуратуру» як гарантія незалежності прокурора [1]. У цьому сенсі велике значення має не лише сама процедура, але й особливості організації суб'єктів розв'язання питання щодо дисциплінарної відповідальності прокурорів, їхнього статусу.

Варто зазначити, що ці питання на сьогодні звертають на себе дедалі більше уваги дослідників, свідченням чого є роботи О.В. Глуховері [2], А.П. Горзова [3], С.К. Костенка [4; 5], С.Л. Назарука [6], С.В. Подкопаєва [7] та інших авторів. Водночас динаміка змін законодавства в цій сфері зумовлює додатковий розгляд тих із них, які стосуються останніх змін правової основи функціонування суб'єктів розв'язання питання щодо дисциплінарної відповідальності прокурорів та їхнього статусу.

Донедавна головним суб'єктом розв'язання питання щодо дисциплінарної відповідальності прокурорів була Кваліфікаційно-дисциплінарна комісія прокурорів (далі - КДКП), створення та функціонування якої передбачалося низкою статей Закону України «Про прокуратуру» 2014 року (у редакції станом на 1 січня 2019 року I. P.) [8]. Вона розпочала свою роботу у травні 2017 року, а безпосередньо з реалізації компетенції щодо дисциплінарної відповідальності - у серпні того ж року [9, с. 4]. Загалом, незважаючи на наявні недоліки в її роботі, запровадження діяльності такого органу було принципово новим кроком у бік посилення незалежності прокурорів. 
Усього за час функціонування КДКП (2 роки - I. P.) їі секретаріатом зареєстровано 4604 дисциплінарних скарги на прокурорів. За результатами їх розгляду членами КДКП ухвалено 859 рішень про відкриття дисциплінарного провадження; у 3668 випадках відмовлено у відкритті проваджень. За результатами дисциплінарних проваджень на прокурорів було накладено 305 дисциплінарних стягнень, 3 яких: у виді догани 116 (38 \%); заборони на термін до одного року на переведення до органу прокуратури вищого рівня чи на призначення на вищу посаду в органі прокуратури, у якому прокурор обіймає посаду - 110 (36 \%); звільнення 3 посади в органах прокуратури - 79 (26\%) [10, с. 349-350].

Ухвалення у вересні 2019 року Закону України № 113-IX «Про внесення змін до деяких законодавчих актів України щодо першочергових заходів із реформи органів прокуратури» (далі - Закон № 113-IX) започаткувало собою сучасний етап реформи прокуратури в нашій країні [11]. Його положеннями, серед іншого, передбачено, що з дня набрання ним (Законом № 113-IX - I. Р.) чинності члени й голова КДКП вважаються звільненими $з$ посади, а їхні повноваження вважаються достроково припиненими (п. п. 2 п. 21 розділу II); у Законі України «Про прокуратуру» слова «Кваліфікаційно-дисциплінарна комісія прокурорів» в усіх відмінках замінено словами «відповідний орган, що здійснює дисциплінарне провадження» (п. п. 4, 5, 7, 9, 14, 20, 21, 23-30, 33, 35-39 та ін. п. 21 розділу I). Водночас п. 22 розділу II установлено, що тимчасово, до 1 вересня 2021 року: в Oфici Генерального прокурора, у кожній обласній прокуратурі утворюються відповідні кадрові комісії як органи для забезпечення розгляду дисциплінарних скарг про вчинення прокурором дисциплінарного проступку та здійснення дисциплінарного провадження щодо прокурорів (п. п. 7), а Генеральний прокурор визначає перелік, склад і порядок роботи кадрових комісій Офісу Генерального прокурора, обласних прокуратур; порядок розгляду кадровою комісією скарг про вчинення прокурором дисциплінарного проступку та процедуру здійснення дисциплінарного провадження; порядок ухвалення кадровою комісією рішення за результатами дисциплінарного провадження і за наявності підстав, передбачених Законом України «Про прокуратуру», про накладення на прокурора Офісу Генерального прокурора, обласної та окружної прокуратури дисциплінарного стягнення або про неможливість подальшого перебування особи на посаді прокурора (п. п. 8).

У цьому сенсі доводиться констатувати факт відходу від уже досягнутого рівня забезпечення незалежності прокурорів, адже на сьогодні питання про дисциплінарну відповідальність прокурорів розв'язує суб'єкт - кадрова комісія, склад якої формується відповідно до наказу Генерального прокурора, тобто ним одноособово із фактично підпорядкованих йому працівників [12].

Згідно з абз. 2 п. 3 Порядку роботи кадрових комісій, затвердженого Наказом Генерального прокурора від 17 жовтня 2019 року № 233, така комісія утворюється у складі семи осіб із працівників органів прокуратури, прокурорів та інших залучених осіб за їхньою згодою. Водночас п. 4 цього Порядку передбачено, що іiї склад затверджує Генеральний прокурор, який визначає також голову та секретаря [13].

Натомість відповідно до ч. 1 ст. 74 Закону України «Про прокуратуру» (у попередній редакції до внесених 19 вересня 2019 року змін) склад КДКП формувався: по-перше, Всеукраїнською конференцією прокурорів, яка призначала п'ять прокурорів; по-друге, з'їдом представників юридичних вищих навчальних закладів 
та наукових установ, який призначав двох учених; по-третє, з'їздом адвокатів України, який призначав одну особу (адвоката); по-четверте, Уповноваженим Верховної Ради України з прав людини, який за погодженням із комітетом Верховної Ради України, до предмету відання якого належить організація та діяльність органів прокуратури, призначав до складу КДКП трьох осіб.

Наказом Генерального прокурора від 4 листопада 2019 року № 266 для визначення процедури розгляду зазначеною кадровою комісією скарг про вчинення прокурором дисциплінарного проступку, а також звернень щодо неналежного виконання прокурором, який обіймає адміністративну посаду, посадових обов'язків, встановлених для відповідної адміністративної посади, здійснення дисциплінарного провадження, ухвалення рішення за результатами дисциплінарного провадження, було затверджено Порядок розгляду кадровою комісією скарг про вчинення прокурором дисциплінарного проступку, здійснення дисциплінарного провадження та ухвалення рішення за результатами дисциплінарного провадження [14]. Аналіз його змісту свідчить про відповідність передбаченої ним процедури дисциплінарного провадження нормам, які містяться в Законі України «Про прокуратуру» (нині їхню дію призупинено - I. P.) та в Положенні про порядок роботи Кваліфікаційно-дисциплінарної комісії прокурорів, що ухвалене Всеукраїнською конференцією прокурорів 27 квітня 2017 року, хоча з деякими винятками [15].

За інформацією Офісу Генерального прокурора, упродовж січня-серпня 2020 року на розгляд кадрової комісії надійшла загалом 831 дисциплінарна скарга. За результатами розгляду відкрито 221 дисциплінарне провадження, щодо 607 скарг члени кадрової комісії ухвалили рішення про відмову у відкритті дисциплінарного провадження.
За результатами розгляду питань на засіданнях кадрової комісії ухвалено 142 рішення стосовно 170 осіб, з яких 114 рішень про закриття дисциплінарного провадження щодо 139 осіб та 13 рішень про накладення дисциплінарного стягнення у виді догани стосовно 14 прокурорів, 12 рішень про накладення дисциплінарного стягнення у виді звільнення 3 посади в органах прокуратури - щодо 14 прокурорів, а також 3 рішення про накладення дисциплінарного стягнення $\mathrm{y}$ виді заборони на термін до одного року на переведення до органу прокуратури вищого рівня чи на призначення на вищу посаду в органі прокуратури, у якому прокурор обіймає посаду, стосовно 3 прокурорів [16].

Як ми вище звертали увагу, діяльність цієї кадрової комісії згідно з п. 22 розділу II Закону № 113-IX має тимчасовий характер - до 1 вересня 2021 року. Після настання цього терміну набудуть чинності норми п. 7 ч. 8 ст. 8 - 1 ; п. 6 ч. 1 ст. 9 ; п. 5 ч. 1 ст. 11 ; п. п. 3 і 4-1 ч. 1 ст. 13 ; ч. 2 ст. 28 ; ст. ст. 29 , $31,32-35,37,38$; ч. ч. $4,5,7,8$ ст. 39 ; ч. 3 ст. 45 ; ч. ч. $1-8$, абз. 1 ч. 9 , ч. ч.10, 11 ст. 46 ; ст. 47 ; ч. ч. $1-3,5-9$ ст. 48 ; ч. 6 ст. 49 ; ст. 60 ; п. п. 3 і 5 ч. 2 ст. 67 ; п. 1 ч. 9 ст. 71 ; ст. ст. $73-76$; ч. ч. $1-3$ ст. 77 ; ст. ст. 78, 79 Закону України «Про прокуратуру», дію яких було зупинено абз. 2 п. 2 розд. II Закону № 113-IX. Відповідно робота кадрової комісії припиниться і має почати своє функціонування «відповідний орган, що здійснює дисциплінарне провадження».

Статус цього органу на сьогодні визначено ст. 73 Закону України «Про прокуратуру», і загалом він є тотожним до статусу КДКП, яка функціонувала раніше. Тому логіка законодавця щодо зміни назви для нас не є зрозумілою, адже порядок формування та компетенція відповідного органу залишаються такими самими.

У підсумку варто зазначити, що не досить обгрунтовані та опрацьовані 
зміни законодавства, поверхові реформи, що мають у своїй основі політичний складник, лише розбалансовують систему прокуратури в
Україні, зменшуючи ефективність іiі діяльності та, відповідно, їі можливості щодо захисту прав і свобод людини, інтересів суспільства та держави.

\section{Список використаних джерел}

1. Про прокуратуру : Закон України від 14 жовтня 2014 року № 1697-VII. URL: http://zakon0.rada.gov.ua/laws/show/1697-18.

2. Глуховеря О.В. Деякі особливості реалізації своїх повноважень Кваліфікаційно-дисциплінарною комісією прокурорів. Науковий вісник Дніпропетровського державного університету внутрішніх справ. 2016. № 1. С. 195-201.

3. Горзов А.П. Структура адміністративно-правового статусу Кваліфікаційно-дисциплінарної комісії прокурорів. Науковий вісник Міжнародного гуманітарного університету. Серія : Юриспруденція. 2015. Вип. 15 (1). С. 112-114.

4. Костенко С.К. Удосконалення порядку формування складу Кваліфікаційно-дисциплінарної комісії прокурорів. Юридичний бюлетенъ. 2018. № 7. Т. 2. С. 76-83.

5. Костенко С.К. Кваліфікаційно-дисциплінарна комісія прокурорів: правовий статус та шляхи реформування. Київ : Національна академія прокуратури України, 2019. 242 с.

6. Назарук С.Л. Кваліфікаційно-дисциплінарна комісія прокурорів - вагомий крок на шляху до європейського співтовариства. Наукові записки [Центральноукраӥнського державного педагогічного університету імені Володимира Винниченка]. Серія : Право. 2017. Вип. 2 (спецвип.). С. 142-145.

7. Подкопаєв С.В. Основні напрями вдосконалення правової основи організації та діяльності Кваліфікаційно-дисциплінарної комісії прокурорів. Тези доповіді на конференцї «Актуальні проблеми судового права» : матеріали Міжнар. наук.-практ. конф., м. Харків, 23 квіт. 2018 р. / редкол. Л.М. Москвич (голова) та ін. Харків : Право, 2018. C. $105-111$.

8. Про прокуратуру : Закон України від 14 жовтня 2014 року № 1697-VII (у редакції станом на 1 січня 2019 року). URL: https://zakon.rada.gov.ua/laws/show/1697-18/ ed20190101\#Text.

9. Збірник рішень Кваліфікаційно-дисциплінарної комісії прокурорів у дисциплінарному провадженні (за 2017 рік) / упоряд.: С.В. Подкопаєв, С.В. Гриненко. Харків : Право, 2018. 944 с.

10. Подкопаєв С.В. Організація та діяльність прокуратури в Україні : монографія. Харків : Право, 2020. 364 с.

11. Про внесення змін до деяких законодавчих актів України щодо першочергових заходів із реформи органів прокуратури : Закон України від 19 вересня 2020 року № 113-IX. URL: https://zakon.rada.gov.ua/laws/show/113-20\#Text.

12. Про створення кадрової комісії з розгляду дисциплінарних скарг про вчинення прокурором дисциплінарного проступку та здійснення дисциплінарного провадження щодо прокурорів : Наказ Генерального прокурора від 9 січня 2020 року № 9. URL: https:/ / old.gp.gov.ua/ua/file_downloader.html? $m=$ fslib\&_t=fsfile\&_c=download\&file_id=209499.

13. Порядок роботи кадрових комісій : затверджено Наказом Генерального прокурора від 17 жовтня 2019 року № 233. URL: https://old.gp.gov.ua/ua/file_downloader. html?_m=fslib\&_t=fsfile\&_c=download\&file_id=207573.

14. Порядок розгляду кадровою комісією скарг про вчинення прокурором дисциплінарного проступку, здійснення дисциплінарного провадження та ухвалення рішення за результатами дисциплінарного провадження : затверджено Наказом Генерального прокурора від 4 листопада 2019 року № 266. URL: https://old.gp.gov.ua/ua/file_downloader. html? $\mathrm{m}=$ fslib\&_t $=$ fsfile\&_c=download\&file_id $=208587$.

15. Положення про порядок роботи К̈валіфікаційно-дисциплінарної комісії прокурорів : ухвалено Всеукраїнською конференцією прокурорів 27 квітня 2017 року. URL: https://zakon.rada.gov.ua/laws/show/n0003900-17\#Text. 
16. Результати діяльності кадрової комісії з розгляду дисциплінарних скарг про вчинення прокурором дисциплінарного проступку та здійснення дисциплінарного провадження щодо прокурорів за 8 місяців 2020 року. URL: https://www.gp.gov.ua/ua/ dvpr?_m=publications\&_t=rec\&id=280049.

Русанова I. O. Суб'єкти розв'язання питання щодо дисциплінарної відповідальності прокурорів

У статті розглядаються проблемні питання, які стосуються зміни правової основи організації та діяльності суб’єктів розв’язання питання щодо дисциплінарної відповідальності прокурорів. Зазначається про важливість не лише дисциплінарної процедури, але й особливостей організації відповідних суб'єктів, компетентних у цій сфері, а також їхнього статусу.

Надається відповідна статистична інформація про результати роботи Кваліфікаційно-дисциплінарної комісії прокурорів, а також кадрової комісії з розгляду дисциплінарних скарг про вчинення прокурором дисциплінарного проступку та здійснення дисциплінарного провадження щодо прокурорів.

Йдеться про помилковість підходу законодавця в частині припинення ним діяльності Кваліфікаційно-дисциплінарної комісії прокурорів, склад якої формувався різними за своєю природою суб’єктами, що забезпечувало її незалежність і соціальний контроль за розв'язанням кадрових питань. Констатується факт відходу від досягнутого рівня забезпечення незалежності прокурорів, адже на сьогодні питання про дисциплінарну відповідальність прокурорів розв’язує кадрова комісія, яка була сформована одноособово Генеральним прокурором із фактично підпорядкованих йому працівників. Крім того, сама процедура розгляду кадровою комісією скарг про вчинення прокурором дисциплінарного проступку, здійснення нею дисциплінарного провадження визначається відповідним Порядком, який затверджено так само Генеральним прокурором.

Звертається увага на тимчасовий характер діяльності такої кадрової комісії та початок функціонування після 1 вересня 2021 року «відповідного органу, що здійснює дисциплінарне провадження». Ставиться під сумнів логіка та раціональність законодавця щодо зміни ним назви «Кваліфікаційно-дисциплінарна комісія прокурорів» на «відповідний орган, що здійснює дисциплінарне провадження», адже порядок їх формування та компетенція є тотожними.

Наголошується на тому, що постійні безсистемні зміни в цій сфері, які стосуються статусу уповноважених суб'єктів і відповідних процедур, украй негативно позначаються на забезпеченні незалежності прокурорів і, як наслідок, у більш широкому розумінні - на діяльності прокуратури загалом, яка згідно зі ст. 1 Закону України «Про прокуратуру» спрямована на захист прав і свобод людини, інтересів суспільства та держави.

Ключові слова: прокурори, Кваліфікаційно-дисциплінарна комісія прокурорів, кадрова комісія; відповідний орган, що здійснює дисциплінарне провадження.

Русанова И. А. Субъекты решения вопроса о дисциплинарной ответственности прокуроров

В этой статье рассматриваются проблемные вопросы, касающиеся изменения правовой основы организации и деятельности субъектов решения вопроса о дисциплинарной ответственности прокуроров. Отмечается важность не только дисциплинарной процедуры, но и особенностей организации соответствующих субъектов компетентных в этой сфере, а также их статуса.

Предоставляется соответствующая статистическая информация о результатах работы квалификационно-дисциплинарной комиссии прокуроров, а также кадровой комиссии по рассмотрению дисциплинарных жалоб о совершении прокурором 
дисциплинарного проступка и осуществления дисциплинарного производства в отношении прокуроров.

Речь идет об ошибочности подхода законодателя в части прекращения им деятельности квалификационно-дисциплинарной комиссии прокуроров, состав которой формировался различными по своей природе субъектами, что обеспечивало ее независимость и социальный контроль решения кадровых вопросов. Констатируется факт ухода от достигнутого уровня обеспечения независимости прокуроров, ведь на сегодняшний день вопрос о дисциплинарной ответственности прокуроров решает кадровая комиссия, которая была сформирована единолично Генеральным прокурором с фактически подчиненных ему работников. Кроме того, сама процедура рассмотрения кадровой комиссией жалоб о совершении прокурором дисциплинарного проступка, осуществления им дисциплинарного производства определяется соответствующим Порядком, который утвержден так же Генеральным прокурором.

Обращается внимание на временный характер деятельности такой кадровой комиссии и начало функционирования после 1 сентября 2021 года «соответствующего органа, осуществляющего дисциплинарное производство». Ставится под сомнение логика и рациональность законодателя относительно изменения им названия «Квалификационно-дисциплинарная комиссия прокуроров» на «соответствующий орган, осуществляющий дисциплинарное производство», ведь порядок их формирования и компетенция являются тождественными.

Подчеркивается, что постоянные бессистемные изменения в этой сфере, касающиеся статуса уполномоченных субъектов и соответствующих процедур, крайне негативно сказываются на обеспечении независимости прокуроров и, как следствие, в более широком смысле - на деятельности прокуратуры в целом, которая согласно ст. 1 Закона Украины «О прокуратуре» направлена на защиту прав и свобод человека, интересов общества и государства.

Ключевые слова: прокуроры, Квалификационно-дисциплинарная комиссия прокуроров, кадровая комиссия; соответствующий орган, осуществляющий дисциплинарное производство.

Rusanova I. Subjects of the resolving the issue concerning the disciplinary responsibility of prosecutors

This article examines issues related to changes in the legal basis for the organization and activities of the subjects of resolving issues of disciplinary responsibility of prosecutors. It is noted the importance of not only the disciplinary procedure itself, but also the peculiarities of the organization of the relevant entities competent in this area, as well as their status.

The prosecutor and the implementation of disciplinary proceedings of prosecutors provide all the necessary statistical information on the results of the work of the qualification and disciplinary commission of prosecutors, as well as the personnel commission for the consideration of disciplinary complaints about the commission of a disciplinary offense. The falsity of the legislator's approach in the field of suspension of the activities of the qualification and disciplinary commission of prosecutors, which composition was formed by different entities, which ensured its independence and social control in resolving personnel issues, is considered. It is stated the fact of the departure from the achieved level of ensuring the independence of prosecutors, because today the issue of disciplinary responsibility of prosecutors is decided by the personnel commission, which was formed by the Attorney General from the employees actually subordinated to him. In addition, the procedure for considering complaints about the commission of a disciplinary offense by the disciplinary commission and the conduct of disciplinary proceedings by it is carried out in an appropriate manner, also approved by the Attorney General.

The temporary nature of the activities of such a personnel commission is taken into account, as well as the commencement of work after September 1, 2021 of the corresponding 
body carrying out the disciplinary proceedings. The logic and rationality of the legislator is questioned in connection with his change of the name "Qualification and Disciplinary Commission of Prosecutors" to "Relevant body carrying out disciplinary proceedings", since the procedure for their formation and conduct are similar.

It is emphasized that constant unsystematic changes in this area concerning the status of authorized subjects and relevant procedures have an extremely negative effect on ensuring the independence of prosecutors and as a result, in a broader sense, on the activities of the prosecutor's office as a whole, which according to the provision 1 of the Law of Ukraine "About the prosecutor's office" is aimed at protecting human rights and freedoms, the interests of society and the state.

Key words: prosecutors, Qualification and Disciplinary Commission of Prosecutors, Personnel Commission, relevant body conducting disciplinary proceedings. 